\title{
Kapasitas Daya Tampung Hijauan Pakan Ternak dan Hasil Ikutan Perkebunan Kelapa Sawit di Kecamatan Tanggetada Kabupaten Kolaka
}

\section{(Feed Capacity of Cattle from by-products of Oil Palm Plantation in Tanggetada District, Kolaka Regency)}

\author{
Muhammad Amrullah Pagala'), Deki Zulkarnain ${ }^{1)}$, Laode Muh Munadi' ${ }^{2}$ \\ ${ }^{1)}$ Fakultas Peternakan Universitas Halu Oleo, Indonesia \\ ${ }^{2)}$ Program Studi Peternakan Pascasarjana Universitas Halu Oleo, Indonesia \\ ${ }^{1)}$ Email: amrullah.pagala@uho.ac.id
}

\author{
Riwayat Naskah \\ Naskah diterima:13 Desember 2019 \\ Naskah direvisi: 16 Feberuari 2020 \\ Disetujui diterbitkan: 29 April 2020
}

\begin{abstract}
Abstrak : The purpose of this study was to determine the carrying capacity of forage and the by-product of oil palm plantations as feed for Bali cattle in Tanggetada District. This research method was carried out by observing the forage potential of feed ingredients based on the production of feed ingredients multiplied by the harvested area and expressed in dry matter (BK). Sampling was carried out by sampling / tiling for animal feed. Forage as research material is grasses, leguminous pods and by-products of oil palm plantations. The method of data analysis uses regional capacity analysis. The results showed that there were 9 types of forage, 2 types of leguminous pods, 2 types of puzzle puzzles and 4 types of plantation waste as animal feed identified in Tanggetada District The production of forage dry materials and by-products of palm oil could meet the consumption needs of Bali cattle in Tanggetada District. The results of the capacity analysis show that Tanggetada District has the ability of the area to accommodate 28,292 Bali cattle from a total population of Bali cattle of 2,338.
\end{abstract}

Keywords: carrying capacity forage; results of oil palm plantation; Tanggetada

Intisari: Tujuan dari studi ini adalah untuk mengetahui daya dukung hijauan dan hasil ikutan perkebunan kelapa sawit sebagai pakan ternak sapi Bali di Kecamatan Tanggetada. Metode studi dilakukan dengan cara mengobservasi potensi hijauan bahan pakan berdasarkan produksi bahan pakan dikalikan dengan luas panen dan dinyatakan dalam bahan kering (BK). Pengambilan sampel dilakukan secara cuplikan/pengubinan hijauan pakan ternak. Hijauan sebagai materi studi adalah golongan rumput-rumputan, polong polongan, teki tekian dan hasil ikutan perkebunan kelapa sawit. Metode analisis data menggunakan analisis daya tampung wilayah. Hasil studi menunjukkan bahwa terdapat 9 jenis hijauan, 2 jenis polong polongan, 2 jenis teki tekian serta 4 jenis limbah ikutan perkebunan sebagai pakan ternak yang teridentifikasi di Kecamatan Tanggetada. Produksi bahan kering hijauan dan hasil ikutan kelapa sawit tersebut dapat memenuhi kebutuhan konsumsi ternak sapi Bali di Kecamatan Tanggetada. Hasil analisis kapasitas tampung menunjukkan bahwa Kecamatan Tanggetada memiliki kemampuan wilayah menampung ternak sapi sebesar 28.292 ekor sapi Bali dari total populasi sapi bali sebesar 2.338 ekor.

Kata kunci : daya dukung hijauan; hasil ikutan perkebunan kelapa sawit; Tanggetada

\section{PENDAHULUAN}

Hijauan pakan ternak dan hasil ikutan perkebunan kelapa sawit merupakan salah satu sumber pakan yang berpotensi sebagai pengembangan ternak sapi bali. Hal ini didukung oleh ketersediaan pakan ternak yang berasal dari jenis hijauan yang berasal dari tanaman sela perkebunan serta hasil ikutan perkebunan kelapa sawit. Setiap harinya ternak ruminansia membutuhkan lebih dari 60 persen hijauan untuk dikonsumsi, baik dalam bentuk segar maupun dalam bentuk kering. Kondisi tersebut menjawab keluhan beberapa peternak yang sering mengeluhkan kekurangan hijauan makan ternak disebabkan oleh degradasi lahan, akibat tingginya aktifitas pembangunan pada suatu 
daerah. Ternak ruminansia memiliki konsumsi hijauan cukup tinggi salah satunya adalah ternak sapi bali.

Kecamatan Tanggetada merupakan salah satu kecamatan yang masuk kedalam administratif Kabupaten Kolaka yang memiliki luas wilayah $275.71 \mathrm{~km}^{2}$ dengan luas perkebunan kelapa sawit 518.00 ha dan populasi ternak sapi bali sebanyak 2.338 ekor yang tersebar di beberapa desa di Kecamatan Tanggetada (Badan Pusat Statistik Kabupaten Kolaka, 2018). Jumlah populasi tersebut masih tergolong rendah dibanding kabupaten lain di Sulawesi Tenggara. Berdasarkan sudut pandang wilayah Kecamatan Tanggetada memiliki potensi yang cukup besar sebagai pengembangan ternak sapi bali. Hasil studi menunjukkan bahwa daerah ini masih memiliki banyak lahan kosong yang cukup potensial untuk dijadikan sebagai lahan pengembangan ternak ruminansia dengan cara mengintegrasi perkebunan kelapa sawit dan ternak sapi bali. Masyarakat petani-peternak di Kecamatan Tanggetada mengembangkan usaha ternak sapi dengan memanfaatkan hijauan berupa rumput lapang, polong polongan, teki tekian dan beberapa rumput unggul serta hasil ikutan perkebunan. Kendala utama adalah produksi hijauan yang dihasilkan dalam menunjang pengembangan ternak sapi bali Kecamatan Tanggetada belum di ketahui dengan jelas jumlahnya. Berdasarkan pemikiran tersebut maka dilakukan studi dengan tujuan menganalisis daya dukung hijauan dan hasil ikutan perkebunan kelapa sawit sebagai pakan ternak sapi bali di Kecamatan Tanggetada.

\section{METODE STUDI}

Objek studi ini adalah lahan sumber hijauan makanan ternak dan jenis hijauan pakan ternak sapi bali pada perkebunan kelapa sawit dengan populasi mencapai 2.338 ekor ternak sapi bali tahun 2018. Sumber data merupakan data primer dan data sekunder. Sampel lokasi diambil sebanyak 3 desa pada 1 kecamatan yang berbatasan langsung dengan perkebunan kelapa sawit di Kabupaten Kolaka dengan pertimbangan jumlah populasi ternak ruminansia terbanyak, dan semua penduduk yang memiliki ternak ruminansia diambil sebagai responden. Merode pengumpulan data dilakukan dengan teknik wawancara dengan menggunakan daftar pertanyaan, yang diarahkan untuk mempelajari aspek pemberian pakan dan jenis pakan yang sering diberikan mulai dari hijauan rumput, polong polongan, teki tekian dan serta hasil ikutan perkebunan kelapa sawit. Potensi hijauan bahan pakan dan hasil ikutan dihitung berdasarkan produksi bahan pakan dikalikan dengan luas panen dan dinyatakan dalam bahan kering (BK). Produksi sampel hijauan diperoleh dari pengambilan hijauan pakan ternak dengan menggunakan kuadran 1x1 Meter. Penetapan cuplikan dilakukan dengan membagi hamparan perkebunan kelapa sawit menjadi 5 bagian secara diagonal dengan mempertimbangkan kontur lahan, kondisi tanaman dan kemudahan untuk di jangkau (Infitria dan Khalil, 2014). Sedangkan untuk hasil ikutan perkebunan dianalisis berdasarkan jumlah produksi hasil ikutan perkebunan sawit dalam setiap bulan. Perhitungan untuk menganalisis kapasitas daya tampung hijauan dengan menggunakan analisis vegetasi gulma dengan rumus summed dominance ratio (SDR) yang dapat menggambarkan dominansi gulma pada suatu areal tertentu dalam menguasai sarana tumbuh yang didapatkan dari besaran Kerapatan Mutlak (KM), Frekuensi Mutlak (FM), Kerapatan Nisbi (KN), Frekuensi Nisbi (FN), dan Nilai Penting (NP). Kerapatan dihitung dengan satuan individu. (Moenadir, 1993).

\section{HASIL DAN PEMBAHASAN}

Perkembangan populasi ternak sapi BBaliali Kecamatan tanggetada menunjukkan tren yang cukup baik. Kenaikan populasi terjadi pada ternak sapi yaitu pada tahun 2016 mencapai 2.143 ekor, tahun 2017 naik menjadi 2.208 ekor, dan tahun 2018 mencapai 2.338 ekor. Keadaan populasi ternak berdasarkan desa juga sangat diperlukan dalam perencanaan penyusunan pengembangan ternak sesuai dengan daya dukung wilayah. 


\section{Ketersediaan Hijauan Pakan Ternak}

Hasil observasi lapangan terdapat beberapa jenis hijauan makanan ternak yang tersebar di Kecamatan Tanggetada. Hijauan tersebut terdiri dari jenis rumput-rumputan, polong polongan, teki tekian. Diantaranya adalah untuk jenis rumput yaitu Elausine Indica (L) Gaertn memiliki luas panen 15.40 Ha, Axonopus Compresus (SW) P. Beauv dengan luas pemanen 70.43 Ha, Braehiaria Mutica (Forsk.) Stapf memiliki luas pemanen 8.80 Ha, Ischaemum Muticum (L) 8.80 Ha, Cyrtococcum Acerencens $31.91 \mathrm{Ha}$, Digitaria Cilliaris 8.80 Ha, Ischaemum Timorense Kunth 26.41 Ha, Pennisetum Purpureum 2.20 Ha dan Imperata Cylindical 12.10 Ha. Sementara untuk jenis teki tekian Cyperus Rotundus L. 15.40 Ha dan Cyperus Kyllingia $14.30 \mathrm{Ha}$, serta untuk jenis Polong polongan yaitu Alysicarpus Vaginalis (L.) DC. 29.71 Ha dan Dismodium Triflorum (L.) DC. $11.00 \mathrm{Ha}$.

\section{Ketersediaan Pakan Hasil Ikutan Perkebunan Sawit}

Hasil industri perkebunan kelapa sawit dikategotikan kedalam tujuh bagian diantaranya adalah pelepah sawit, lumpur sawit, bungkil inti sawit, daun kelapa sawit, serat perasan, tandan kosong dan batang sawit. Pelepah sawit diperoleh dari hasil pemangkasan yang dilakukan rutin 6 bulan sekali. Sedangkan lumpur sawit merupakan ikutan yang dihasilkan dalam proses pemerasan buah sawit. Bungkil inti kelapa sawit adalah salah satu hasil ikutan industri kelapa sawit di mana produksinya cukup melimpah. Karena itu, upaya penggunaan ikutan ini untuk pakan telah pula dilakukan yakni sebagai sumber energi atau protein. Sementara itu untuk pelepah dan daun sawit sebagai pakan ternak dilakukan inklusi maksimal berupa pengolahan melalui teknologi pakan, salah satunya dengan fermentasi (Wan Zahari, 2003). Serat perasan merupakan hasil ekstraksi minyak sawit yang mempunyai kandungan gizi dan nilai pencernaan 24-30 persen atau yang lebih rendah sehingga pemanfaatannya belum banyak disarankan (Diwyanto, 2004). Tandan kosong sawit (TKS) merupakan ikutan dari pabrik kelapa sawit (PKS) yang jumlahnya sekitar 55-58 persen dari tandan buah segar.

\section{Kapasitas Daya Tampung Hijauan Pakan Ternak}

Perhitungan kapasitas daya tampung selalu mempertimbangkan nilai PUF bahwa rumput alam sebanyak 60 persen dan alang alang sebanyak 10 persen dan hutan 40 persen tanaman sela merupakan tanaman yang terdapat disela-sela tanaman perkebunan seperti jambu mente, kopi, kakao, kelapa dalam dan lain sebagainya. Produksi tanaman sela sebanyak 20 persen produksi padang rumput $(20$ persen $X 6,178=1,235,6 \mathrm{~kg} / \mathrm{ha} / \mathrm{th})$. Dasar asumsi perhitungan kapasitas tampung ternak (Caring Capacity) berdasarkan penggunaan lahan dilakukan dengan perhitungan bahwa, pada lahan hutan dapat memproduksi sebanyak $1 / 10$ kali rumput alam padang rumput $(0,1$ x $6,178=617,8 \mathrm{~kg} / \mathrm{ha} / \mathrm{th}$ ) padang rumput terdiri dari 70 persen rumput alam dan 30 persen alang alang sawah menghasilkan rumput alam dan alang alang sebanyak 30 persen panen pertahun dari padang rumput $(3,089 \mathrm{~kg} / \mathrm{ha} / \mathrm{tahun})$ produksi rumput alam sebanyak $6,178 \mathrm{bk} / \mathrm{kg} / \mathrm{tahun}$. Produksi alang alang sebanyak 6,336 bk/kg/tahun. (Nafiu, dkk. 2017). Studi yang sebelumnya di lakukan oleh (Abadi, M. dkk, 2019). Kabupaten Muna Barat. Produksi bahan kering hijauan tersebut dapat memenuhi kebutuhan konsumsi ternak sapi dan kambing di Kabupaten Muna Barat. Hasil analisis KPPTR menunjukkan bahwa Kabupaten Muna Barat memiliki kemampuan wilayah menampung ternak sapi sebesar 2.669 ekor, dan ternak kambing sebesar 3.293 ekor.

Kapasitas daya tampung hijauan yang berada di Kecamatan Tanggetada memiliki beberapa jenis hijauan pakan ternak yang biasa dijadikan sebagai sumber pakan ternak seperti Eleusine indica (L.) Gaertn dengan luas panen 15,41 Ha dengan produksi 95,19 ton dengan jumlah kapasitas daya tampung ternak sebanyak 28,98 ekor. Sementara untuk jenis hijauan Axonopus compresus (SW.) P. Beauv yang berada diperkebunan kelapa sawit mampu menampung kapasitas daya tampung ternak sebanyak 132.47 ekor. Begitupan dengan jenis hijauan Brachiaria mutica (Forsk.) Stapf dengan kapasitas tampung ternak 16.56 ekor, Imperata cylindrical 22.77 ekor, Ischaemum muticum (L.) 16.56 ekor, Cyrtococcum accrencens 60.02 ekor, Digitaria cilliaris 16.56 ekor, Ischaemum timorense kunth 49.68 ekor, Pennisetum purpureum 26.80 ekor, Cyperus rotundus L. 28.98 ekor, Cyperus kylingia 26.91 ekor, Alysicarpus vaginalis 55.89 ekor dan jenis hijauan yang Desmodium triflorum yang memiliki luas pemanenan 11.01 hektar memiliki kapasitas daya 
tampung sebanyak 20.70 ekor. Sehingga untuk total kapsistas tampung ternak sebanyak 480.20 ekor Ternak. Untuk lebih jelasnya disajikan pada Tabel 1.

\section{Kapasitas Daya Tampung Hasil Ikutan Perkebunan Kelapa Sawit}

Menurut Diwyanto (2004), bahwa biomasa atau produk samping yang dihasilkan dari tanaman dan pengolahan kelapa sawit untuk setiap satu satuan luas tanaman kelapa sawit (ha) dalam setahun adalah 10.011 metrik kg bahan kering. Untuk lebih jelasnya disajikan pada Tabel 2.

Hasil ikutan perkebunan sawit yang berada dilokasi studi Kecamatan Tanggetada dengan luas perkebunan 518.00 Ha memiliki jumlah hasil ikutan seperti pelepah sawit berjumlah 907.735 ton/bulan, kemudian untuk hasil ikutan lumpur sawit berjumlah 39.212.87 ton/bulan. Sedangkan untuk bungkil inti sawit memiliki hasil ikutan sejumlah 29.938 .44 ton/bulan dengan potensi pakan tersebut memungkinkan untuk pengembangan ternak berbasis hasil ikutan perkebunan kelapa sawit. Selanjutnya untuk hasil ikutan perkebunan kelapa sawait berupa daun kelapa sawit berjumlah 69.041 ton/bulan. Serta untuk hasil ikutan kelapa sawit terbanyak adalah tandan kosong dengan total hasil ikutan berjumlah 662.561 .04 ton/bulan. Untuk lebih jelansnya di sajikan pada tabel 3.

Perkebunan kelapa sawit Kecamatan Tanggetada memiliki total kapasitas tampung sebanyak 27,812 ekor yang terbagi kedalam beberapa bagian berdasarkan kapasitas tampung hasil samping industri perkebunan kelapa sawit. Perkebunan kelapa sawit yang berada di Kecamatan Tanggetada memiliki hasil ikutan perkebunan kelapa sawit yang bisa di manfaatkan sebagai pakan ternak. Seperti jenis hasil ikutan perkebunan kelapa sawit berupa daun sawit dengan berat kering 340,740 $\mathrm{kg} /$ tahun mampu menampung kebutuhan pakan ternak sebanyak 104 ekor. Selain itu terdapat hasi likutan perkebuan lain yang dapat dimanfaatkan yaitu lumpur sawit dengan total kapasitas tampung sebanyak 8,071 ekor ternak karena didukung dengan jumlah berat kering lumpur sawit sebanyak $26,513,428 \mathrm{~kg} / \mathrm{tahun}$. Jumlah hasil ikutan perkebunan kelapa sawit berupa bungkil inti sawit dapat menampung kapasitas ternak sebanyak 482 ekor. Berbeda dengan kapasitas tampung hasil ikutan perkebunan sawit berupa tandan kosong mampu menampung ternak sebanyak 19,155 ekor ternak. Karena hal ini didukung oleh jumlah berat kering dari tandan kosong yang cukup melimpah sebanyak 62,924,220 kg/tahun. Untuk lebih jelasnya disajikan pada Tabel 4.

\section{Komposisi dan Kualitas Pakan Hasil Ikutan Perkebunan Kelapa Sawit}

Komposisi dan kualitas hasil ikutan perkebunan kelapa sawit menunjukkan bahwa pelepah sawit kadar Bahan Kering (BK) sebanyak 26,07 persen dan Kadar Abu sebesar 5,10 persen dengan total Protein Kasar 3,07 persen. Akan tetapi pada pelepah sawit memiliki Serat Kasar (SK) yang cukup tinggi 50,94 persen sehingga memerlukan perlakuan khusus dalam proses pemberian pakan kepada ternak. Kemudian pada pelepah sawit memiliki Lemak Kasar (LK) hanya 1,07 persen. Sementara untuk total Karbohidrat (BETN) 39,82 persen dengan komposisi kalsium 0,96 persen kadar fospor (P) 0,08 persen.

Lumpur sawit adalah hasil ikutan perkebunan sawit yang dihasilkan dalam proses pemerasan buah sawit untuk menghasilkan minyak sawit kasar dengan bahan kering sebesar 24,06 persen. Sementara itu untuk kadar abu lumpur sawit memiliki kadar sebesar 14,40 persen dan protein kasar 15,58 persen. Akan tetapi lumpur sawit memiliki serat kasar yang cukup sedikit dengan total 35,8 persen dan karbohidrat 16,36 persen. Lumpur sawit merupakan salah satu pakan alternatif yang sangat baik untuk pengembangan ternak Sapi Bali karena memiliki kalsium sebanyak 1,08 persen dan fospor sebesar 0,25 persen. Bungkil inti kelapa sawit adalah inti kelapa sawit yang telah mengalami proses ekstrasi dan pengeringan. Selain itu bungkil inti kelapa sawit dapat digunakan sebagai pakan ternak bungkil kelapa sawit ini termaksud dalam jenis pakan konsetrat atau pakan penguat dengan bahan kering 91,83 persen kemudian untuk kadar abu 4,14 persen, protein kasar 16,33, serat kasar 36,68 persen, lemak kasar 6,49, karbohidrat 28,19, kalsium 0,56 persen dan fospor 0,84 .

Kandungan serat kasar ikutan kelapa sawit cukup tinggi, khususnya daun yaitu 21,52 persen Kandungan protein kasar daun sawit cukup baik yaitu 14,12 persen. Sedangkan untuk bahan kering memiliki kandungan yaitu 46,18 persen, kadar abu 13,40 persen, lemak kasar 4,37 persen, karbohidrat 46,59, kalsium 0,84 persen dan fospor 0,17persen. Kelapa sawit yang memiliki ikutan tandan kosong yang merupakan sisa dari tandan kelapa sawit segar yang sudah diambil manfaat 
daging buahnya. Tandan kosong kelapa sawit ini bisa dijadikan hal yang bermanfaat antara lain menjadi bahan bakar biofuel yang berupa bioethanol dan juga bisa menjadi pupuk kompos bagi tanaman dan sebagai pakan ternak. Akan tetapi tadan kosong pada perkebunan kelapa sawit memiliki kadar bahan kering yang cukup tinggi sehingga membutuhkan pengolahan terlebih dahulu sebelum diberikan kepada ternak sebagai pakan. Sementara untuk bahan kering pada tandan kosong yaitu 92,10 persen, kadar abu 7,89 persen, protein kasar 3,70 persen, serat kasar 47,93 persen, lemak kasar 4,70 persen, kalsium 0,24persen dan fhospor 0,04 persen. Untuk lebih jelasnya komposisi dan kualitas pakan hasil ikutan perkebunan kelapa sawit disajikan pada Tabel 5.

\section{KESIMPULAN DAN SARAN}

Produksi bahan kering berupa hijauan makanan ternak yang berada disela tanaman perkebunan kelapa sawit dan hasil ikutan perkebunan dapat menampung serta memenuhi kebutuhan pakan ternak sapi Bali dalam rangka pengembangan ternak berbasis hasil ikutan perkebunan dan hijauan. Terdapat 12 jenis hijauan dengan total kapasitas tampung 480.20 ekor satuan ternak. Sedangkan untuk hasil ikutan perkebunan kelapa sawit dengan 4 jenis hasil ikutan mampu menampung kapasitas daya tampung ternak sebanyak 27.812 ekor.

\section{DAFTAR PUSTAKA}

Abadi. M, Surahmanto, Rizal. A, Nasiu.F, Fatmawati. (2019). Daya Dukung Hijauan Sebagai Pakan Ternak Sapi Dan Kambing Di Kabupaten Muna Barat Provinsi Sulawesi Tenggara. Buletin Peternakan 43 (3), 151-157.

Badan Pusat Statistik Kabupaten Kolaka (2018). Kabupaten Kolaka Dalam Angka. Kabupaten Kolaka.

Diwyanto, K, Prawiradiputra, B.R., Lubis, D. (2004). Integrasi Tanaman-Ternak dalam Pengembangan Agribisnis yang Berdaya Saing dan Berkelanjutan. Wartazoa, 12, 1-8.

Infitria, K. (2014). Studi produksi dan kualitas hijauan di lahan padang rumput UPT peternakan Universitas Andalas Padang. Buletin Makanan Ternak. 101 (1), 25-33.

Moenandir, J. (1993). Ilmu Gulma. Jakarta: Raja Grafindo Persada.

Nafiu, Ld, Saili, T., Aku, AS., Karim, J., Abadi, M. (2017). Blue Print Peternakan Kabupaten Konawe Selatan, Kerjasama Dinas Peternakan dan Kesehatan Hewan Kabupaten Konawe Selatan. Kendari.

Nurhayu, A. Ishak, A.B.L dan Ella, A. (2015). Pelepah dan Daun Sawit Sebagai Pakan Substitusi Hijauan Pada Pakan Ternak Sapi Potong Di Kabupaten Luwu Timur Sulawesi Selatan. Balai Pengkajian Teknologi Pertanian Sulawesi Selatan.

Wan Zahari, M., Hassan , O.A., Wong , H.K. and Liang, J.B. (2003). Utilization oil palm frondbased diet for beef cattle production in Malaysia. Asian-Aust. J. Anim. Sci. 16 (4), 625634. 
Tabel 1. Kapasitas Daya Tampung Hijauan Pakan Ternak Kecamatan Tanggetada

\begin{tabular}{|l|c|c|c|c|c|c|}
\hline Jenis Hijauan & $\begin{array}{c}\text { Luas } \\
\text { Panen (ha) }\end{array}$ & $\begin{array}{c}\text { Pro.BK/kg } \\
\text { /tahun }\end{array}$ & $\begin{array}{c}\text { Produksi } \\
\text { (kg) }\end{array}$ & $\begin{array}{c}\text { Konsumsi } \\
\text { BK/ekor/ } \\
\text { tahun }\end{array}$ & $\begin{array}{c}\text { Produksi } \\
\text { (ton) }\end{array}$ & KTT \\
\hline $\begin{array}{l}\text { Eleusine indica (L.) } \\
\text { Gaertn }\end{array}$ & 15.40 & 6178 & 95,190 & 3285 & 95.19 & 28.98 \\
\hline $\begin{array}{l}\text { Axonopus compresus } \\
\text { (SW.) P. Beauv. }\end{array}$ & 70.43 & 6178 & 435,164 & 3285 & 435.16 & 132.47 \\
\hline $\begin{array}{l}\text { Brachiaria mutica } \\
\text { (Forsk.) Stapf }\end{array}$ & 8.80 & 6178 & 54,394 & 3285 & 54.39 & 16.56 \\
\hline Imperata cylindrical & 12.10 & 6178 & 74,792 & 3285 & 74.79 & 22.77 \\
\hline $\begin{array}{l}\text { Ischaemum muticum } \\
\text { (L.) }\end{array}$ & 8.80 & 6178 & 54,394 & 3285 & 54.39 & 16.56 \\
\hline $\begin{array}{l}\text { Cyrtococcum } \\
\text { accrencens }\end{array}$ & 31.91 & 6178 & 197,181 & 3285 & 197.18 & 60.02 \\
\hline Digitaria cilliaris & 8.80 & 6178 & 54,394 & 3285 & 54.39 & 16.56 \\
\hline $\begin{array}{l}\text { Ischaemum timorense } \\
\text { kunth }\end{array}$ & 26.41 & 6178 & 163,185 & 3285 & 163.18 & 49.68 \\
\hline $\begin{array}{l}\text { Pennisetum } \\
\text { purpureum }\end{array}$ & 2.20 & 6178 & 13,598 & 3285 & 13.60 & 4.14 \\
\hline Cyperus rotundus L. & 15.40 & 6178 & 95,190 & 3285 & 95.19 & 28.98 \\
\hline Cyperus kylingia & 14.30 & 6178 & 88,393 & 3285 & 88.39 & 26.91 \\
\hline Alysicarpus vaginalis & 29.71 & 6178 & 183,583 & 3285 & 183.58 & 55.89 \\
\hline Desmodium triflorum & 11.00 & 6178 & 67,995 & 3285 & 67.99 & 20.70 \\
\hline & 255.33 & & $1,620,156$ & & $1,577.45$ & 480.20 \\
\hline Total Kapasitas Tampung & & & & & $\mathbf{4 8 0 . 2 0}$ \\
\hline
\end{tabular}

Sumber : analisis data primer, 2019

Tabel 2. Produk Samping Tanaman dan Olahan Kelapa Sawit Untuk Setiap Hektar

\begin{tabular}{|c|l|c|c|c|}
\hline No & \multicolumn{1}{|c|}{ Biomasa } & $\begin{array}{c}\text { Segar } \\
(\mathbf{K g})\end{array}$ & $\begin{array}{c}\text { Bahan Kering } \\
\text { (persen) }\end{array}$ & $\begin{array}{c}\text { Bahan Kering } \\
(\mathbf{K g})\end{array}$ \\
\hline 1 & Pelepah Sawit & 6.292 & 26.07 & 1.642 \\
\hline 2 & Lumpur Sawit & 4.704 & 24.07 & 1.132 \\
\hline 3 & Bungkil Inti Sawit & 564 & 91.83 & 514 \\
\hline 4 & Daun Kelapa Sawit & 1.430 & 46.18 & 658 \\
\hline 5 & Tandan Kosong & 3.680 & 92.10 & 3.386 \\
\hline
\end{tabular}

Sumber : Dwiyanto, 2004.

Tabel 3. Jenis Hasil Ikutan Perkebunan Kelapa Sawit di Lokasi Studi

\begin{tabular}{|l|l|r|}
\hline No & Jenis Ikutan & Ton/Bulan \\
\hline 1 & Pelepah Sawit & 76.790 .735 \\
\hline 2 & Lumpur Sawit & $39.212,87$ \\
\hline 3 & Bungkil Inti Sawit & $29.938,44$ \\
\hline 4 & Daun Kelapa Sawit & 69.041 \\
\hline 5 & Tandan Kosong & $662.561,04$ \\
\hline Jumlah & $\mathbf{1 . 7 0 8 . 4 8 7}$ \\
\hline
\end{tabular}

Sumber : PT. Damai Jaya Lestari, 2019 
Tabel 4. Kapasitas Daya Tampung Hasil Ikutan Perkebunan Kelapa Sawit

\begin{tabular}{|c|l|r|r|r|r|r|r|}
\hline Luas Lahan & Jenis Hasil Ikutan & $\begin{array}{c}\text { Jumlah Hasil } \\
\text { Ikutan } \\
\text { Keseluruhan } \\
\text { bulan/Ha }\end{array}$ & $\begin{array}{c}\text { Jumlah Hasil } \\
\text { Ikutan/Thn }\end{array}$ & $\begin{array}{c}\text { Hasil Ikutan } \\
\text { Berat Basah } \\
\text { Kg/Thn }\end{array}$ & $\begin{array}{c}\text { Hasil Ikutan } \\
\text { Berat Kering } \\
\text { Kg/Thn }\end{array}$ & $\begin{array}{c}\text { Kebutuhan } \\
\text { Pakan } \\
\text { BK/Ekor/T } \\
\text { hn }\end{array}$ & KTT \\
\hline 518.00 & Daun sawit & 67,340 & $1,481,480$ & 740,740 & 340,740 & 3285 & 104 \\
\hline 518.00 & Lumpur Sawit & $8,080,800$ & $96,969,600$ & $28,509,062$ & $26,513,428$ & 3285 & 8,071 \\
\hline 518.00 & Bungkil Inti Sawit & 1,820 & $3,771,040$ & $45,252,480$ & $1,583,837$ & 3285 & 482 \\
\hline 518.00 & Tandan Kosong & $24,781,120$ & $297,373,440$ & $68,395,891$ & $62,924,220$ & 3285 & 19,155 \\
\hline & & & & & & & $\mathbf{2 7 , 8 1 2}$ \\
\hline
\end{tabular}

Sumber : analisis data primer, 2019

Tabel 5. Komposisi dan Kualitas Pakan Hasil Ikutan Kelapa Sawit

\begin{tabular}{|l|c|c|c|c|c|c|c|c|}
\hline \multirow{2}{*}{$\begin{array}{c}\text { Bahan/Produk } \\
\text { Samping Sawit }\end{array}$} & BK & Abu & PK & SK & LK & BETN & Ca & P \\
\cline { 2 - 9 } & persen & persen & persen & persen & persen & persen & persen & persen \\
\hline Pelepah Sawit & 26,07 & 5,10 & 3,07 & 50,94 & 1,07 & 39,82 & 0,96 & 0,08 \\
\hline Lumpur Sawit & 24,06 & 14,40 & 15,58 & 35,8 & 14,78 & 16,36 & 1,08 & 0,25 \\
\hline Bungkil Inti Sawit & 91,83 & 4,14 & 16,33 & 36,68 & 6,49 & 28,19 & 0,56 & 0,84 \\
\hline Daun Kelapa Sawit & 46,18 & 13,40 & 14,12 & 21,52 & 4,37 & 46,59 & 0,84 & 0,17 \\
\hline Tandan Kosong & 92,10 & 7,89 & 3,70 & 47,93 & 4,70 & - & 0,24 & 0,04 \\
\hline
\end{tabular}

Sumber : Nurhayu, dkk. 2015. 